\title{
Editorial RES 1/2020
}

By the time the Review of Ecumenical Studies was launching the call for papers for this issue, the review had completed its tenth year of existence. It seemed like a proper moment to look back on the publication manifesto of its initial days and ponder where its mission lies today, as well as where the ecumenical movement is at the present, in its numerous facets. After experiencing an ebullient reception in the second half of the $20^{\text {th }}$ century, ecumenism seems to have entered a more nuanced phase in recent times, with different rhythms and objectives depending on the confessions involved and the cultural area in question. The very enthusiasm of its early years was what fed the foundations of the Review of Ecumenical Studies, which has since evolved from a local, Romanian language review, to an international academic journal, with contributions in English and German. Some may argue that in the meantime, ecumenism has been overridden by the more stringent necessity for interreligious dialogue, due to the tensions with parts of the Arab world and the migrant crisis in Europe. Others may argue that the official ec umenical meetings have lost their significance, and the genuine interest in finding a common ground of discussion has become less relevant, since globalisation has been creating an actual
Als die Redaktion das Thema für diese Nummer von RES festlegte, hatte unsere Zeitschrift gerade ihr zehntes Erscheinungsjahr hinter sich. Es schien ein guter Moment zu sein, sich an das Programm zu erinnern, das an ihrem Anfang stand, und darüber nachzudenken, worin ihre Aufgabe heute besteht. Eng damit verbunden ist die Frage nach dem Stand und den Zielen der gegenwärtigen ökumenischen Bewegung und nach ihren verschiedenen Facetten. Auf diese Frage gibt es - nach der Blütezeit der Ökumene in der zweiten Hälfte des 20. Jahrhunderts - heute sehr unterschiedliche Antworten, je nachdem auf welche Konfession und welchen kulturellen Raum man blickt. Die Gründung von $R E S$ war geprägt von der Begeisterung der ersten Jahre und hat dazu geführt, dass sie von einer lokalen, vorwiegend rumänischsprachigen Zeitschrift zu einem internationalen akademischen Forum wurde, mit Beiträgen in englischer und deutscher Sprache. Man könnte einwenden, dass der interreligiöse Dialog heute viel dringlicher sei als die ökumenische Begegnung, und dabei auf die Spannungen in der arabischen Welt und die Migrationskrise verweisen. Andere kritische Stimmen urteilen, dass die offiziellen ökumenischen Treffen mit ihrer Suche nach einem gemeinsamen theologischen Fundament ihre Bedeutung verloren hätten, da an- 
meeting sphere for the various confessions to come naturally in contact with one another. Moreover, counterreactions to globalisation are gaining their own terrain, by resorting to a return to, and cultivation of, local customs, values and beliefs, and thus leading to a decrease in the interest of knowing and understanding the other.

But one of the most remarkable indicators that ecumenism still has an active, albeit at times latent, impact is the voice of theologians whose research is focused on religious services - the most conservative forms of religious expression - as they call for a discussion on possible anti-ecumenical elements in specific liturgical details. One such contribution is offered in the current RES issue by Maria Takala-Roszczenko, as she examines how the idea of church unity has the potential to be an instrument for antagonising communities of faith today. It is often the case when this idea is interwoven with claims of various religious communities to what true faith and salvation consist of. This can be noticed in the hymnography of saints from seventeen century Polish-Lithuanian lands, such as the Greek-Catholic saint Josafat Kuntsevych, the Orthodox saint Afanasiy Filippovych, and the Roman Catholic saint Andrzej Bobola. Their canonisation dossiers have been built precisely upon their fight (and eventual martyrdom in some cases) against other confessions, gesichts der Globalisierung ganz neue Räume der Begegnung eröffnet worden seien. Wieder andere verweisen auf eine wachsende Gegenbewegung zur Globalisierung mit einer Rückkehr zur Pflege lokaler Traditionen, Werte und Glaubensvorstellungen, wodurch das Interesse an der Kenntnis und dem Verständnis für andere in den Hintergrund tritt.

Ein bemerkenswerter Indikator für die bleibende Bedeutung der ökumenischen Frage ist die Stimme von Theologen, die über den Gottesdienst und somit über die konservativste Ausdrucksform religiösen Glaubens nachdenken und dabei nach möglichen antiökumenischen Elementen in der Liturgie fragen. Ein solcher Beitrag in dieser Nummer von RES stammt von Maria Takala-Roszczenko. Sie untersucht, inwiefern die Vorstellung der kirchlichen Einheit das Potenzial hat, christliche Gemeinschaften gegeneinander aufzubringen, wenn diese Vorstellung mit dem Anspruch auf den Besitz des wahren Glaubens und auf Heilsvermittlung verbunden ist. Solche Beispiele finden sich in der Hymnographie, die sich auf Heilige des siebzehnten Jahrhunderts im polnisch-litauischen Raum bezieht, nämlich den griechisch-katholischen Heiligen Josafat Kuntsevych, den orthodoxen Heiligen Afanasiy Filippovych und den römisch-katholischen Heiligen Andrzej Bobola. Deren Prozess der Heiligsprechung hat sich im Besonderen auf den Kampf um den wahren Glauben 
and consequently, the hymnography that recalls them in the liturgy also recalls the conflictual topoi against the confession they fought. Because liturgical worship influences at a structural level the way a community perceives itself, Takala raises the question of whether the continued veneration of such saints does not also continuously rekindle hostility towards other communities.

Another indicator of latent ecumenism is the cultivated attention that churches pay to each other with regards to events that take place within the community of the other, such was the Reformation anniversary of 2017. Hans Bruno Fröhlich reviews the materials that document the perception of the $500^{\text {th }}$ anniversary of the Reformation in Romanian Orthodoxy. The papers that he brings into scrutiny differ either by publication medium (be they from official church news portals or academic journals), or in the aspects that they cover: the historical relationship between Orthodox and Lutherans in Transylvania, the publication in Romanian of commented translations of sermons by Martin Luther, the awarding of the distinction of doctor honoris causa to the Ecumenical Patriarch Bartholomew by the Faculty of Protestant Theology in Tübingen, the positive view on the Reformation by Pope Francis, or the importance of Lutheran concepts, such as the concept of freedom or sola scriptura, that may be also (und in einigen Fällen deren Martyrium) konzentriert; die entsprechenden liturgischen Hymnen sind daher unweigerlich von den umstrittenen Punkten im Konflikt mit anderen Konfessionen geprägt. Weil nun wiederum die Liturgie das Selbstverständnis der feiernden Gemeinde mitbestimmt, stellt Takala die Frage, ob die Verehrung dieser Heiligen nicht dazu führt, dass die Feindseligkeit zwischen den religiösen Gruppen ständig neu genährt wird.

Ein anderer Indikator für die Ökumenekann es sein zu prüfen, inwiefern Kirchen wichtigen Ereignissen in anderen christlichen Gemeinschaften Aufmerksamkeit schenken, wie z.B. während des Reformationsjubiläums 2017. Hans Bruno Fröhlich analysiert das Material, das bei dieser Gelegenheit in der rumänischen orthodoxen Kirche publiziert wurde. Es ist unterschiedlich, was das Medium (offizielle kirchliche Nachrichtendienste oder akademische Zeitschriften) und was die Themen betrifft: die historischen Beziehungen zwischen der Orthodoxie und dem Luthertum in Siebenbürgen, rumänische Übersetzungen und Kommentare von Predigten Martin Luthers, die Verleihung der Ehrendoktorwürde an den ökumenischen Patriarchen Bartholomäus durch die Evangelischtheologische Fakultät Tübingen, die positive Sicht von Papst Franziskus auf die Reformation oder Grundbegriffe lutherischer Theologie, wie etwa die Freiheit oder das sola scriptu$r a$, die auch für die Orthodoxie 
relevant for the Orthodox theology. These echoes of the Reformation are not just courtesy media coverages or opportunities to popularise to the Orthodox public common knowledge on Lutheranism, but they may occasion, as the author quotes from the analysed sources, self-reflection and self-improvement within the Romanian Orthodox milieu.

What ecumenism has been contributing to as a lasting aspect is this increased need for self-understanding and an imperative to regulate one's relationship to the others based on this re(de)fined knowledge. The best recent example of the complexities such a process might entail is the 2016 Holy and Great Council of the Orthodox Church which came after a long travail of preparation and marked the beginning of an intricate discussion about the ecclesiological theology of the Orthodox Church. Alexandru-Marius Crișan takes up the conciliar Document on Ecumenical Relations, as well as the various forms this document has had prior to its approval, as a guide in understanding how the Orthodox perspectives on ecumenism have evolved in the past century. Pondering the arguments of those who have endorsed the document and, on the other hand, of its critics, the author identifies two competing ecclesiological views that seem to dominate the discussions - the exclusivist, Unam Sanctam, ecclesiology and, respectively, an ecclesiology bedeutsam sein könnten. Solche Stellungnahmen waren nicht nur Höflichkeitsbekundungen in den Medien oder Gelegenheiten, um allgemein bekannte Urteile über das Luthertum innerhalb der Orthodoxie zu wiederholen, sondern nach dem Urteil des Autors boten sie auch Anlass zur Selbstbesinnung und gaben Gedankenanstöße für die rumänische Orthodoxie.

Eine bleibende Bedeutung der Ökumene liegt auch darin, dass sie jeden Partner zu einer vertieften Selbstvergewisserung führt, um von da ausgehend die Beziehung zu den anderen zu klären. Das beste Beispiel für die Komplexität eines solchen Prozesses stellt das Heilige und Große Konzil der Orthodoxen Kirche von 2016 dar. Es war der Abschluss einer langen und mühseligen Vorbereitung und der Beginn einer schwierigen Diskussion über die Ekklesiologie der Orthodoxen Kirche. Alexandru-Marius Crișan bespricht das Konzilsdokument zu den ökumenischen Beziehungen und seine verschiedenen Vorentwürfe, um besser $\mathrm{zu}$ verstehen, wie sich die orthodoxe Perspektive auf die Ökumene im Verlauf des vergangenen Jahrhunderts verändert hat. Unter Abwägung der Argumente, die zur Annahme des Dokuments oder aber zur Kritik an ihm geführt haben, kommt der Autor zum Schluss, dass es um zwei konkurrierende ekklesiologische Sichtweisen geht: die exklusivistische Auffassung (Unam 
that understands other confessions as parts of the Church as well, to differing degrees. The opponents of the document identified this second attempt as an ecclesiology of the branches, a view firmly rejected by the author of the article.

Variations in internal understanding and church regulations tallies at times the most unexpected details in ecumenical meetings, as one may find, for example, in the ecumenical encounters between the Evangelical Lutheran Church of Finland, the Orthodox Church of Finland, and, correspondingly, the Russian Orthodox Church. Heta Hurskainen's study reviews the themes that have been discussed at these meetings, especially in the past decade that has recorded the most numerous bilateral encounters of its kind. Hurskainen follows with a keen eye how the gender balance in the composition of the Lutheran delegations has been kept, since the Evangelical Lutheran Church of Finland had decided to allot at least thirty percent of the membership to female representatives. The author argues that this element of gender justice has not been consistently observed, to the point that some sessions, especially in the 2010s, have had no female members at all, a change that one can correlate with domestic changes in Finland also in terms of social changes, and with the thematic shift the dialogues have taken. While earlier sessions cultivated
Sanctam) einerseits, das Verständnis der anderen Konfessionen als - wiewohl gradmäßig abgestufter - Teil der Kirche andererseits. Die Gegner des Dokuments bezeichnen diese zweitgenannte Auffassung als „Ekklesiologie der Verzweigungen“, was aber der Autor selber vehement ablehnt.

Innerkirchliche Entwicklungen zeigen sich gelegentlich an unerwarteten Details in den ökumenischen Dialogen, wie man am Beispiel der Begegnungen zwischen der Evangelischen Kirche in Finnland, der Orthodoxen Kirche in Finnland respektive der Russischen Orthodoxen Kirche zeigen kann. Der Aufsatz von Heta Hurskainen gibt einen Überblick über die Themen, die an diesen Begegnungen diskutiert wurden, mit einem Schwerpunkt auf den letzten zehn Jahren, in denen besonders viele solche bilaterale Treffen stattfanden. Aufmerksam analysiert sie, inwieweit das Gender-Gleichgewicht in der Zusammenstellung der lutherischen Delegationen gewahrt wurde, seit die Evangelische Kirche Finnlands entschieden hatte, dass der Anteil der Frauen zumindest 30 Prozent betragen sollte. Die Gendergerechtigkeit sei allerdings nicht durchgehend beachtet worden, ja es habe - vor allem in den 10er Jahren - sogar Begegnungen ganz ohne Teilnahme von Frauen gegeben. Diese Beobachtung korreliert mit teils auch sozialen Veränderungen in Finnland und mit neuen Themenstellungen der Dialoge. Während in einer frühe- 
ecclesiological topics, Christian anthropology and marriage have dominated the last discussions, revealing that bilateral dialogues follow the dynamic that is usually imprinted by local situations of the Churches entering that dialogue.

The meeting in 2016 between the Evangelical Lutheran Church of Finland and the Russian Orthodox Church failed to conclude with a common communique, but this was not the only such meeting to end up like this. It is indeed very much in the spirit of ecumenism to encourage the continuation of dialogues even when there is no agreement in sight. Such an open approach to encounters one may also find in the Gadamerian understanding of dialogue and Zdenko Sirka's article shows that the developments of $20^{\text {th }}$ century hermeneutics not only influenced theological views and practices, and became an important "topic of convergence" in the patristic movement, but that it has irremediably underpinned the ecumenical movement. Many of the themes that have shaped the ecumenical hermeneutics of the past century, such as context, reception, tradition, conversation, the ability to listen with consideration, and the importance of not dismissing ongoing questions are shared with philosophical hermeneutics and especially with the hermeneutics of Hans-Georg Gadamer.

The features that ecumenism may display today - some of which have ren Phase ekklesiologische Themen behandelt wurden, ging es nun um christliche Anthropologie und um die Ehe. Die Entwicklung der bilateralen Dialoge folgt somit den Fragen, die die beteiligten Kirchen jeweils auch intern beschäftigen.

Am Dialogtreffen von 2016 zwischen der Evangelischen Kirche von Finnland und der Russischen Orthodoxen Kirche konnte man sich nicht auf ein gemeinsames Kommuniqué einigen, was aber nicht das erste Mal vorkam. Es ist gerade im Geist der ökumenischen Begegnungen, auch dann den Dialog weiterzuführen, wenn noch keine Einigung in Sicht ist. Ein solcher offener Ansatz in den Begegnungen kann mit Gadamers Verständnis des Dialogs in Verbindung gebracht werden. Dies aufzuzeigen ist das Ziel des Beitrags von Zdenko Širka: die Entwicklungen der Hermeneutik im 20. Jahrhundert, so der Autor, haben nicht nur die theologischen Ansichten und Methoden geprägt und sind zu einem wichtigen Punkt der Konvergenz in der patristischen Bewegung geworden, sondern stützten auch die ökumenische Bewegung. Es gibt viele thematische Berührungspunkte zwischen der ökumenischen Hermeneutik und der hermeneutischen Philosophie, besonders dem Denken von Hans-Georg Gadamer: Kontext, Rezeption, Tradition, Konversation, die Fähigkeit respektvoll zuzuhören, die Aufmerksamkeit für offen gebliebene Fragen u.a. Einige Merkmale der gegenwärtigen Ökumene kommen in dieser Nummer 
been exemplified in this new issue von RES zur Sprache. Sie zeigen, dass of the RES - could testify against man nicht so sehr von einem verminthe idea of a diminished interest in derten Interesse an der Ökumene reecumenical matters, and rather for den kann, sondern eher davon, dass the fact that essential concepts of wesentliche Elemente der Ökumene ecumenism have already become zu einem selbstverständlichen Teil der integrative parts of contemporary heutigen Theologie geworden sind. Die theologies. The Review of Ecumenical Zeitschrift RES hat über die Jahre hinStudies has experienced over the weg gezeigt, wie in der Vielfalt Themen years, through the variety of the (z.B. Pilgerwesen, Patristik, Euthanasie, topics it has addressed (e.g. pilgrim- Migration, Menschenwürde und Armut, age, patristics, euthanasia, migration, Kirche und Politik) und in den ganz human dignity and poverty, church unterschiedlichen Beiträgen, die dazu and politics etc) and the multifacet- geschrieben wurden, zum Ausdruck ed contributions it has received, that kommt, dass die Ökumene nicht auf ecumenism is not circumscribed to offizielle Treffen beschränkt ist. Sie official meetings alone. It has been wird vielmehr in kritischer Rezeption distilled, through its critical recep- und Praxis zu einer Methode für theotion and practice, into a method for logische und religionswissenschaftliche theological and religious research. Forschung.

Antoaneta Sabău 